\title{
Changes in Levels of Amino Acids and Basic Components in Burley Tobacco Produced by Roasting*
}

\author{
by \\ Peng Li, Ming Wu, and Jianping Xie \\ Zhengzhou Tobacco Research Institute of China National Tobacco Corp., No. 88 Erqi Road, \\ Zhengzhou, Henan, 450000, P.R. China
}

\section{SUMMARY}

Three burley tobacco samples from three different areas in China and Brazil were roasted under three processing conditions. The amino acids and basic components of the burley tobacco samples were determined before and after roasting. Routine tobacco variables (reducing sugars, total water-soluble sugars, total nitrogen, total alkaloids, total volatile bases, and $\mathrm{pH}$ ) were determined according to the Chinese National Standard Methods (CNSM). Free amino acids were determined by high performance liquid chromatography (HPLC). The basic compounds were isolated by use of simultaneous distillation and extraction (SDE) equipment. Their levels were determined qualitatively and quantitatively on a) a gas chromatograph (GC) equipped with a nitrogen-phosphorus detector (NPD) and b) by gas chromatography mass spectrometry (GC-MS). The results indicated that the chemical changes occurring during roasting have a significant impact on burley tobacco quality. Roasting decreased the tobacco $\mathrm{pH}$ value and the levels of total nitrogen, reducing sugars, free amino acids, and other nitrogenous substances, such as amines and alkaloids. The latter are usually related to the irritancy and sharp taste of burley tobacco smoke. In contrast, the levels of pyrazines, important contributors to the characteristic burley flavor, increased. [Beitr. Tabakforsch. Int. 20 (2003) 459-466]

\section{ZUSAMMENFASSUNG}

Drei Burleytabake aus drei verschiedenen Regionen in China und Brasilien wurden unter drei verschiedenen Verarbeitungsbedingungen geröstet. Die Aminosäuren und basischen Verbindungen der Tabakproben wurden vor und nach dem Rösten bestimmt. Routinemäßig bestimmte Tabakvariablen (reduzierende Zucker, Gesamtgehalt an wasserlöslichen Zuckern, Gesamtstickstoff, Gesamtalkaloide, Gesamtgehalt an flüchtigen Basen und $\mathrm{pH}$ ) wurden gemäß der chinesischen Standardmethoden bestimmt. Die freien Aminosäuren wurden mittels Hochleistungsflüssigkeitschromatographie (HPLC) bestimmt. Die basischen Verbindungen wurden durch simultane Destillation und Extraktion (SDE) isoliert und ihre Konzentrationen qualitativ und quantitativ mit a) Gaschromatographie (GC) in Kombination mit einem Stickstoff-Phosphor Detektor (NPD) und mit b) Gaschromatographie-Massenspektrometrie (GC-MS) bestimmt. Die Ergebnisse weisen darauf hin, dass die beim Rösten auftretenden chemischen Veränderungen eine signifikante Auswirkung auf die Qualität des Burleytabaks haben. Durch den Röstvorgang wurde der pH-Wert des Tabaks und der Gehalt an Gesamtstickstoff, reduzierenden Zuckern, freien Aminosäuren und weiteren stickstoffhaltigen Verbindungen wie Aminen und Alkaloiden verringert. Die letztgenannten stehen gewöhnlich in Zusammenhang mit der Reizwirkung und dem strengen Geschmack des Rauches von Burleytabaken. Im Gegensatz hierzu erhöhte sich der Gehalt an Pyrazinen, die für den typischen Geschmack des Burleytabaks verantwortlich sind. [Beitr. Tabakforsch. Int. 20 (2003) 459-466]

\section{RESUME}

Trois échantillons différents de tabac Burley cultivés dans trois régions en Chine et au Brésil ont été torréfiés sous trois conditions de traitement différentes. Les acides aminés et les composants basiques des échantillons du tabac Burley ont été déterminés avant et après torréfaction. Les caractéristiques courantes du tabac (sucres réducteurs, sucres totaux soluble dans l' eau, azote total, alcaloïdes totaux, bases volatiles totales et $\mathrm{pH}$ ) ont été déterminés selon les méthodes normalisées en Chine. Les acides aminés libres ont été dosés au moyen de la chromatographie liquide à haute performance (HPLC), les composants basiques ont été isolés par distillation et extraction simultanée (SDE). Leurs teneurs ont été dosées qualitativement et quantitativement par a) chromatographie gazeuse (GC) avec détecteur azote-phos- 
Table 1. Code names

\begin{tabular}{l|c|c|c|c}
\hline & & \multicolumn{3}{|c}{ Roasting treatment solutions } \\
\cline { 3 - 5 } Burley tobacco samples & $\begin{array}{c}\text { Before } \\
\text { roasting }\end{array}$ & Water & $\begin{array}{c}\text { Aqueous } \\
\text { glucose }\end{array}$ & $\begin{array}{c}\text { Aqueous } \\
\text { ammonia }\end{array}$ \\
\hline Brazil & $\mathrm{A}_{0}$ & $\mathrm{~A}_{1}$ & $\mathrm{~A}_{2}$ & $\mathrm{~A}_{3}$ \\
$\begin{array}{l}\text { Hefeng } \\
\text { control area }\end{array}$ & $\mathrm{B}_{0}$ & $\mathrm{~B}_{1}$ & $\mathrm{~B}_{2}$ & $\mathrm{~B}_{3}$ \\
$\begin{array}{l}\text { Hefeng } \\
\text { non-control area }\end{array}$ & $\mathrm{C}_{0}$ & $\mathrm{C}_{1}$ & $\mathrm{C}_{2}$ & $\mathrm{C}_{3}$ \\
\hline
\end{tabular}

phate (NPD) et par b) chromatographie gazeuse-spectrométrie de masse (GC-MS). Les résultats indiquent que les changements chimiques ayant lieu au cours de la torréfaction exercent un effet significatif sur la qualité du tabac Burley. La torréfaction a réduit le $\mathrm{pH}$ du tabac et les teneurs en azote, sucres réducteurs, acides aminés libres et autres composants azotés, tels que les amines et les alcaloïdes. Ces derniers sont généralement liés à l' effet irritant et au goût amer de la fumée du tabac Burley. Au contraire, les teneurs en pyrazines, contribuant de façon importante au goût caractéristique du tabac Burley, sont augmentées. [Beitr. Tabakforsch. Int. 20 (2003) 459-466]

\section{INTRODUCTION}

In recent years, considerable effort on the development of the low "tar" blended cigarette has been expended by the cigarette industry in China in order to compete with cigarette products imported since China entered the World Trade Organization (WTO). Burley tobaccos constitute about $30 \%$ of the cigarette blend. Heat treatment or the so-called "roasting" of burley tobacco is usually necessary prior to its inclusion in the cigarette blend. The roasting not only reduces consumer unacceptable organoleptic properties of cigarette smoke, e.g., irritation, ammonia odor, but also generates a strong roasted aroma characteristic of that of burley tobacco smoke.

In their 1981 review, LONG and WEYBREW (1) summarized many of the major chemical changes that occur during senescence and curing of tobacco. Also, BURTON et al. (2) described many of the chemical changes that occur during the air curing of burley tobacco. During the roasting of burley tobacco, many chemical reactions, e.g., the Maillard reaction, occur and these have a significant impact on the smoking quality of the cigarette products containing roasted burley tobacco as a significant portion of the blend. Over the years, the composition of burley tobacco has been described in considerable detail. NeURATH et al. (3), ROBERTS and RoHDE (4), and DEMOLE and BeRTHET (5) reported numerous aroma and flavor components identified in burley tobacco. In addition, WANG et al. (6) and MATSUKURA et al. (7) described some of the aromatic and fragrant components in roasted burley tobacco.

Studies on the changes in the levels of routine variables (reducing sugars, total water-soluble sugars, total nitrogen, total alkaloids, total volatile bases) of burley tobacco during roasting were summarized in 1996 by WU and WU (8). However, only a few published studies deal with the volatile flavor components produced in burley tobaccos during roasting. The reason for this lack may possibly be because the reactions during roasting are extremely complex or perhaps because such studies were never published because of their proprietary nature.

Our objective was to determine the changes in the levels of amino acids and basic components of burley tobacco produced by roasting. Routine tobacco variables (reducing and water-soluble sugars, total nitrogen, total alkaloids, total volatile bases) were determined according to the Chinese National Standard Methods (CNSM). Free amino acids were determined by high performance liquid chromatography (HPLC). Basic compounds were obtained with simultaneous distillation and extraction (SDE) equipment. Their levels were determined qualitatively and quantitatively on a) a gas chromatograph (GC) equipped with a nitrogen-phosphorus detector (NPD) and b) by gas chromatography mass spectrometry (GC-MS).

\section{EXPERIMENTAL}

\section{Materials and roasting conditions}

Burley tobacco leaves were collected from Brazil (1998 crop, BYR/S) and the Hefeng demonstration and nondemonstration areas in the Hubei province of China (2000 crop, middle leaves).

Hefeng county is a burley tobacco producing area. A control area was developed where the agriculture experts produced the burley tobaccos under strict management. In this control area, the rate of fertilizer was $75.8 \mathrm{~kg} /$ acre $(187.2 \mathrm{~kg} / \mathrm{ha})$, the ratios of N:P:K were $1: 1.5: 2$. Practices of seedling, transplanting, topping, and field management as well as the curing facilities were improved. As a result, the burley tobaccos in the control area were superior to those in the non-control area.

As described previously (9), the burley tobaccos were treated in three different ways before roasting: With water, aqueous sugar, and aqueous ammonia. They were roasted for 11 minutes. The airflow temperature was $100{ }^{\circ} \mathrm{C}$; the relative humidity was $50 \%$. The tobacco leaves were ground to pass a 40-mesh grid, and stored in sealed containers. The code names assigned to the 12 samples are listed in Table 1.

\section{Reagents}

The following authentic compounds, with purities higher than $97 \%$ (GC), were used: Pyrrole, thiazole, pyridine, 2acetylpyridine, 3-acetylpyridine, 2-ethyl-6-methylpyrazine, 2,3-dimethylpyrazine, 2,5-dimethylpyrazine, trimethylpyrazine, and tributylamine (internal standard). Analytically pure anhydrous sodium sulfate $\left(\mathrm{Na}_{2} \mathrm{SO}_{4}\right)$, dichloromethane $\left(\mathrm{CH}_{2} \mathrm{Cl}_{2}\right)$, sodium hydroxide $(\mathrm{NaOH})$, and hydrochloric acid $(\mathrm{HCl})$ were used during the study.

\section{Instruments}

The following instruments were used: SDE equipment, an in-house-made burley roaster, an HP 1090 II/L HPLC, and an AA3 auto-analysis equipment (BRAN+LUEBBE). An HP 5890 GCII equipped with a nitrogen-phosphorus detec- 


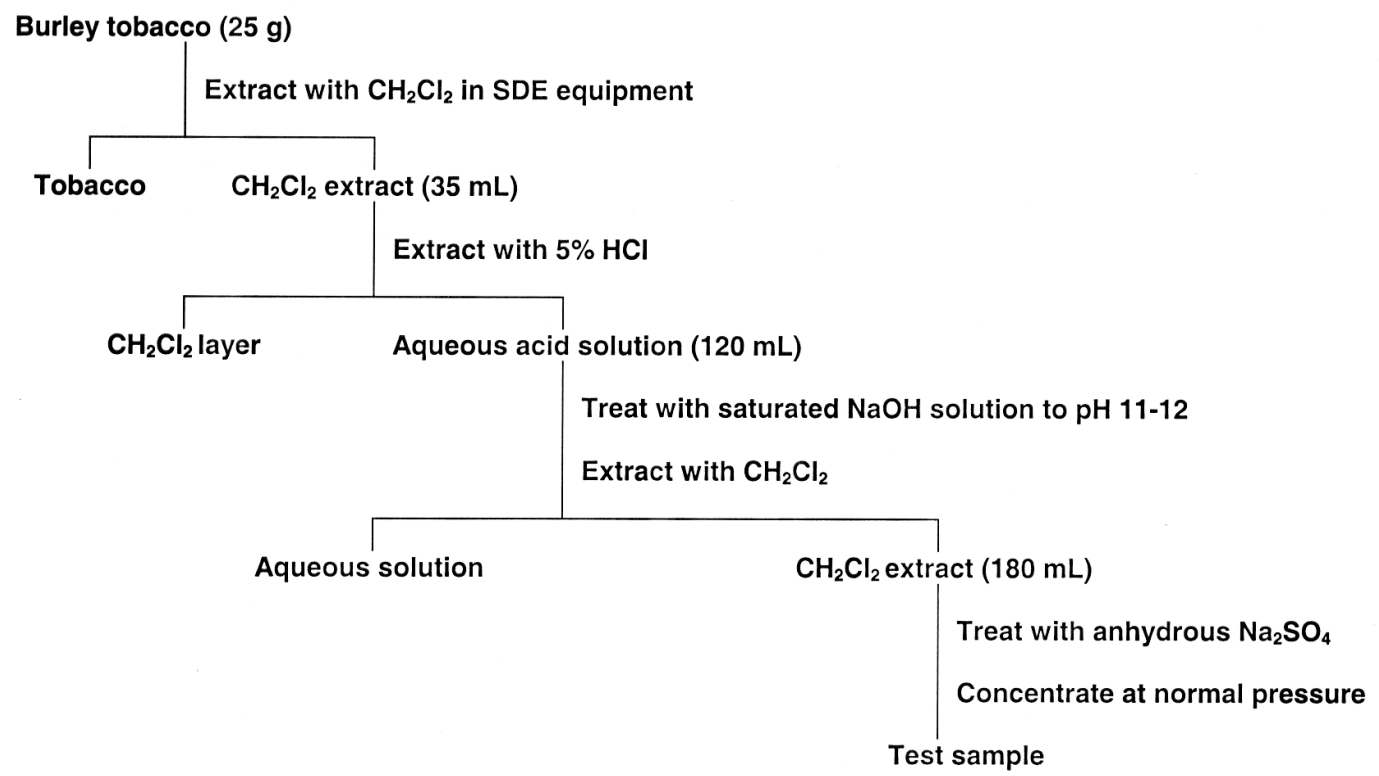

Figure 1. Procedure for extraction and fractionation of basic components from burley tobacco

tor, and an Ultra2 $(50 \mathrm{~m} \times 0.2 \mathrm{~mm}$ i.d. $\times 0.331 \mu \mathrm{m}$ film thickness) capillary column were used. After temperature programming from 70 to $270{ }^{\circ} \mathrm{C}$ at a rate of $2{ }^{\circ} \mathrm{C} / \mathrm{min}$, the temperature was maintained at $270{ }^{\circ} \mathrm{C}$ for $30 \mathrm{~min}$. The split ratio was 20:1. Injection port temperature was $260{ }^{\circ} \mathrm{C}$; detector temperature was $270{ }^{\circ} \mathrm{C}$. Nitrogen was the carrier gas. The GC-MS measurements were made with electron energy of $70 \mathrm{eV}$ on an HP 5973 mass spectrometer connected to an HP 6890 gas chromatograph. GC conditions were as described above. Transfer line temperature was $280{ }^{\circ} \mathrm{C}$, the ion source temperature was $200{ }^{\circ} \mathrm{C}$, the carrier gas was helium, and the mass spectral library was the Wiley/NIST Registry of Mass Spectral Data, 6th Edition.

\section{Determination of routine tobacco variables}

Routine chemical components (reducing and water-soluble sugars, total nitrogen, total alkaloids, total volatile bases) were determined according to the Chinese National Standard Methods (CNSM):

- Determination of reducing sugar and total water-soluble sugar-continuous flow method No. YC/T32 of CNSM, equal to CORESTA No. 38

- Determination of total nitrogen - continuous flow method No. YC/T161 of CNSM

- Determination of total alkaloids - continuous flow method No. YC/T160 of CNSM, equal to CORESTA No. 35

- Determination of total volatile bases - No. YC/T35 of CNSM

- Tobacco $\mathrm{pH}$ values were determined by the extraction method (10).

\section{Determination of free amino acids}

OPA (o-phenyldialdehyde) auto-precolumn derivation reverse-phase HPLC was used to determine the levels of free amino acids in the burley tobaccos before and after roasting (11).

\section{Extraction of basic flavor components}

Ground tobacco $\left(25 \mathrm{~g}\right.$ ) was extracted with $\mathrm{CH}_{2} \mathrm{Cl}_{2}$ by SDE. The extract was extracted three times with a $5 \% \mathrm{HCl}$ solution. The combined acidic extracts were back extracted with $\mathrm{CH}_{2} \mathrm{Cl}_{2}$ to remove residual neutral components. Then, the acidic solution was adjusted to $\mathrm{pH} 11-12$ with saturated $\mathrm{NaOH}$ solution. The basic fraction was obtained by extracting the alkaline solution with $\mathrm{CH}_{2} \mathrm{Cl}_{2}$. The resulting basic fraction solution was treated with anhydrous $\mathrm{Na}_{2} \mathrm{SO}_{4}$, then concentrated at atmospheric pressure to about $1 \mathrm{~mL}$ for $\mathrm{GC}$ and GC-MS analysis (see Figure 1).

\section{Determination of dried substances lost during analysis}

The \% calcium was determined according to CNSM No. GB/T12398-90. The result indicated that the amount of dried substances lost during roasting was so low (round about $0.2 \%$ ) that it was considered negligible.

\section{RESULTS AND DISCUSSION}

\section{Reproducibility and recovery}

Both internal standard and regression equation methods were used for the quantitative determination of the basic components. Tributylamine was used as the internal standard. The concentrations of seven basic components ( 3 pyridines, 4 pyrazines) were calculated from the appropriate regression equations $\left(R^{2}=0.9990-0.9999\right)$. Concentrations of other components were calculated on the basis of the peak area relative to that of the internal standard, tributylamine. It was assumed that these components had the same response as tributylamine to the nitrogen-phosphorus detector. Calibration curves of the seven basic compounds were linear in the calibrated range.

Known amounts of authentic compounds were treated as described above and the $\%$ recovery determined. Five 
Table 2. Results of recovery and reproducibility test $(n=5)$

\begin{tabular}{l|c|c}
\hline Compound & $\begin{array}{c}\text { Recovery, } \\
\%\end{array}$ & $\begin{array}{c}\text { Coefficient of } \\
\text { variation, \% }\end{array}$ \\
\hline Pyridine & 81.8 & 5.70 \\
Pyridine, 2-acetyl- & 94.1 & 1.60 \\
Pyridine, 3-acetyl- & 67.0 & 2.90 \\
Pyrazine, 2,3-dimethyl- & 89.5 & 2.90 \\
Pyrazine, 2,5-dimethyl- & 87.8 & 2.70 \\
Pyrazine, 2-ethyl-3-methyl- & 86.4 & 2.00 \\
Pyrazine, trimethyl- & 93.8 & 2.30 \\
\hline
\end{tabular}

groups of authentic compounds were treated and analyzed under the same experimental and GC conditions and the reproducibility results were obtained. The $\%$ recovery and reproducibility results $(n=5)$ are summarized in Table 2. The recovery of most basic components exceeded $80 \%$. The reproducibility, expressed as coefficient of variation, of most basic components was $7 \%$ or better. Since the level of most of the tobacco components was very low, the reproducibility of this method was considered acceptable.

\section{Routine chemical components}

Routine tobacco variables were determined according to CNSM. The variables determined included: Reducing sugar, total water-soluble sugars, total nitrogen, total plant alkaloids, total volatile bases, and tobacco $\mathrm{pH}$. The results are summarized in Table 3.

The data in Table 3 indicate the following:

1) The amount of reducing sugar obviously decreased. During roasting of the burley tobacco, the reducing sugar was involved in the Maillard reaction and caramelization (Note: When sugar is heated at elevated temperatures, an aroma is generated accompanied by color development. These changes are defined as carameli- zation.) The observation that $\left[\mathrm{B}_{1}-\mathrm{B}_{0}\right]<\left[\mathrm{B}_{3}-\mathrm{B}_{\mathrm{o}}\right]$ and $\left[\mathrm{C}_{1}-\mathrm{C}_{\mathrm{o}}\right]<\left[\mathrm{C}_{3}-\mathrm{C}_{\mathrm{o}}\right]$ indicates that addition of a small quantity of ammonia accelerates the Maillard reaction. The mole ratio of the added amount of ammonia to the decreased amount of reducing sugar was about 1:2.

2) The amount of total sugars increased. The total watersoluble sugars in tobacco is generated by the hydrolysis of starch. The hydrolysis may be described as follows: starch $\rightarrow$ dextrin $\rightarrow$ maltose $\rightarrow$ glucose. While the starch was undergoing hydrolysis to sugars, sugars were consumed through the Maillard reaction and caramelization. From Table 3, we note that $B_{1}>B_{0}, B_{3}>B_{0}, C_{1}>C_{0}$, and $\mathrm{C}_{3}>\mathrm{C}_{\mathrm{o}}$. This means the amount of total sugar produced is greater than the amount consumed. After roasting with aqueous glucose, the total sugar increase is because the amount of added aqueous sugar was too high.

3) The amount of total nitrogen decreased about $10 \%$ during roasting. The decrease may be attributed to the reactions between nitrogen compounds and sugar plus possible vaporization of some nitrogen compounds at high temperature.

4) The amount of total plant alkaloids decreased a little, about $1 \%$ to $7 \%$, because some plant alkaloids either hydrolyzed or vaporized.

5) The amount of total volatile bases decreased. Obviously, a portion of some volatile bases vaporized during the high temperature roasting.

6) The tobacco $\mathrm{pH}$ value decreased. The order of the range of decrease in each series is as follows:

$$
\begin{aligned}
& \left|\mathrm{A}_{3}-\mathrm{A}_{\mathrm{o}}\right|<\left|\mathrm{A}_{1}-\mathrm{A}_{\mathrm{o}}\right|<\left|\mathrm{A}_{2}-\mathrm{A}_{\mathrm{o}}\right| \text { or }|0.34|<|0.38|<|0.47|, \\
& \left|\mathrm{B}_{3}-\mathrm{B}_{\mathrm{o}}\right|<\left|\mathrm{B}_{1}-\mathrm{B}_{\mathrm{o}}\right|<\left|\mathrm{B}_{2}-\mathrm{B}_{\mathrm{o}}\right| \text { or }|0.15|<|0.22|<|0.26| \text {, and } \\
& \left|\mathrm{C}_{3}-\mathrm{C}_{\mathrm{o}}\right|<\left|\mathrm{C}_{1}-\mathrm{C}_{\mathrm{o}}\right|<\left|\mathrm{C}_{2}-\mathrm{C}_{\mathrm{o}}\right| \text { or }|0.11|<|0.11|<|0.16| \text {. }
\end{aligned}
$$

So, under the same roasting condition, the use of aqueous glucose depresses the tobacco $\mathrm{pH}$ more than the other treatments. The decrease of tobacco $\mathrm{pH}$ is due to high temperature oxidation with a resulting increase in highly oxygenated products. At the same time, enhanced Maillard

\begin{tabular}{|c|c|c|c|c|c|c|c|}
\hline Sample & $\begin{array}{l}\text { Reducing } \\
\text { sugar, \% }\end{array}$ & $\begin{array}{c}\text { Total water-soluble } \\
\text { sugars, \% }\end{array}$ & $\begin{array}{c}\text { Total nitrogen, } \\
\% \\
\end{array}$ & $\begin{array}{l}\text { Total plant } \\
\text { alkaloids, \% }\end{array}$ & $\begin{array}{c}\text { Total nitrogen/ } \\
\text { total plant alkaloids }\end{array}$ & $\begin{array}{c}\text { Total volatile } \\
\text { bases, } \%\end{array}$ & $\begin{array}{c}\text { Tobacco } \\
\mathrm{pH}^{\mathrm{a}}\end{array}$ \\
\hline $\begin{array}{l}A_{0} \\
A_{1} \\
A_{2} \\
A_{3}\end{array}$ & $\frac{{ }^{b}}{4.02}$ & $\begin{array}{l}0.20 \\
0.21 \\
4.45 \\
0.25\end{array}$ & $\begin{array}{l}4.36 \\
4.23 \\
4.02 \\
4.33\end{array}$ & $\begin{array}{l}2.46 \\
2.38 \\
2.45 \\
2.28\end{array}$ & $\begin{array}{l}1.77 \\
1.78 \\
1.64 \\
1.90\end{array}$ & $\begin{array}{l}0.94 \\
0.78 \\
0.70 \\
0.67\end{array}$ & $\begin{array}{l}6.81 \\
6.43 \\
6.34 \\
6.47\end{array}$ \\
\hline $\begin{array}{l}B_{0} \\
B_{1} \\
B_{2} \\
B_{3}\end{array}$ & $\begin{array}{l}0.12 \\
0.08 \\
3.79 \\
0.07\end{array}$ & $\begin{array}{l}0.32 \\
0.36 \\
3.99 \\
0.43\end{array}$ & $\begin{array}{l}4.13 \\
4.12 \\
4.00 \\
4.12\end{array}$ & $\begin{array}{l}3.55 \\
3.52 \\
3.32 \\
3.52\end{array}$ & $\begin{array}{l}1.16 \\
1.17 \\
1.20 \\
1.17\end{array}$ & $\begin{array}{l}1.04 \\
0.97 \\
0.93 \\
0.92\end{array}$ & $\begin{array}{l}6.18 \\
5.96 \\
5.92 \\
6.03\end{array}$ \\
\hline $\begin{array}{l}\mathrm{C}_{0} \\
\mathrm{C}_{1} \\
\mathrm{C}_{2} \\
\mathrm{C}_{3}\end{array}$ & $\begin{array}{l}0.15 \\
0.13 \\
3.72 \\
0.12\end{array}$ & $\begin{array}{l}0.27 \\
0.30 \\
3.84 \\
0.37\end{array}$ & $\begin{array}{l}5.50 \\
5.28 \\
5.07 \\
5.04\end{array}$ & $\begin{array}{l}5.69 \\
5.68 \\
5.61 \\
5.58\end{array}$ & $\begin{array}{l}0.97 \\
0.93 \\
0.90 \\
0.90\end{array}$ & $\begin{array}{l}1.25 \\
1.22 \\
1.12 \\
1.07\end{array}$ & $\begin{array}{l}5.88 \\
5.77 \\
5.72 \\
5.77\end{array}$ \\
\hline
\end{tabular}
reactions would also contribute to the $\mathrm{pH}$ decrease.

Table 3. Results from quantitative analysis of routine chemical components of roasted burley tobacco

a The water used showed $\mathrm{pH} 7.23$. 
Table 4. Quantitative results of free amino acids in roasted burley tobacco

\begin{tabular}{|c|c|c|c|c|c|c|c|}
\hline $\begin{array}{l}\text { Amino acids, } \\
\mathrm{mg} / \mathrm{g} \text { dried tobacco powder }\end{array}$ & $A_{0}$ & $A_{1}$ & Change, $\%^{a}$ & $\mathrm{~A}_{2}$ & Change, \% & $\mathrm{A}_{3}$ & Change, \% \\
\hline Aspartic acid & 0.148 & 0.114 & -23.0 & 0.093 & -37.2 & 0.148 & 0.0 \\
\hline Glutamic acid & 0.789 & 0.862 & 9.3 & 0.623 & -21.0 & 0.871 & 10.4 \\
\hline Glutamine + histidine & 0.064 & 0.060 & -6.3 & 0.053 & -17.2 & 0.074 & 15.6 \\
\hline Glycine & 0.015 & 0.017 & 13.3 & 0.017 & 13.3 & 0.019 & 26.7 \\
\hline Threonine & 0.026 & 0.017 & -34.6 & 0.019 & -26.9 & 0.027 & 3.9 \\
\hline Alanine & 0.020 & 0.017 & -15.0 & 0.019 & -5.0 & 0.025 & 25.0 \\
\hline Arginine & 0.031 & 0.029 & -6.5 & 0.030 & -3.2 & 0.036 & 16.1 \\
\hline Tyrosine & 0.010 & 0.013 & 30.0 & 0.008 & -20.0 & 0.009 & -10.0 \\
\hline Methionine & 0.009 & 0.012 & 33.3 & 0.007 & -22.2 & 0.012 & 33.3 \\
\hline Phenylalanine & 0.008 & 0.008 & 0.0 & 0.004 & -50.0 & 0.009 & 12.5 \\
\hline Valine+tryptophan & 0.028 & 0.027 & -3.6 & 0.025 & -10.7 & 0.033 & 17.9 \\
\hline Isoleucine & 0.018 & 0.019 & 5.6 & 0.015 & -16.7 & 0.022 & 22.2 \\
\hline Leucine & 0.013 & 0.017 & 30.8 & 0.013 & 0.0 & 0.018 & 38.5 \\
\hline Lysine & 0.052 & 0.051 & -1.9 & 0.048 & -7.7 & 0.053 & 1.9 \\
\hline \multirow[t]{2}{*}{ Total } & 1.231 & 1.263 & 2.6 & 0.974 & -20.7 & 1.356 & 10.3 \\
\hline & $\mathrm{B}_{0}$ & $\mathrm{~B}_{1}$ & Change, $\%^{a}$ & $\mathrm{~B}_{2}$ & Change, \% & $\mathrm{B}_{3}$ & Change, \% \\
\hline Aspartic acid & 2.050 & 2.12 & 3.56 & 1.762 & -14.1 & 2.152 & 5.0 \\
\hline Glutamic acid & 1.013 & 1.00 & -1.78 & 0.834 & -17.7 & 0.882 & -12.9 \\
\hline Asparagine & 0.318 & 0.30 & 4.72 & 0.272 & -14.5 & 0.280 & -12.0 \\
\hline Serine & 0.127 & 0.20 & 57.48 & 0.094 & -26.0 & 0.172 & 35.4 \\
\hline Glutamine + histidine & 0.217 & 0.23 & 6.45 & 0.162 & -25.4 & 0.229 & 5.5 \\
\hline Glycine & 0.044 & 0.05 & 11.36 & 0.029 & -34.1 & 0.047 & 6.8 \\
\hline Threonine & 0.044 & 0.04 & -2.27 & 0.027 & -38.6 & 0.044 & 0.0 \\
\hline Alanine & 0.042 & 0.04 & 4.76 & 0.057 & 35.7 & 0.033 & -21.4 \\
\hline Arginine & 0.090 & 0.10 & 11.11 & 0.074 & -17.8 & 0.100 & 11.1 \\
\hline Tyrosine & 0.017 & 0.02 & 0.00 & 0.011 & 35.3 & 0.017 & 0.0 \\
\hline Methionine & 0.023 & 0.02 & 0.00 & 0.013 & -43.5 & 0.024 & 4.4 \\
\hline Phenylalanine & 0.100 & 0.10 & 1.00 & 0.063 & -37.0 & 0.090 & -10.0 \\
\hline Valine+tryptophan & 0.055 & 0.05 & -1.82 & 0.036 & -34.6 & 0.051 & -7.3 \\
\hline Isoleucine & 0.149 & 0.16 & 5.37 & 0.106 & -28.9 & 0.144 & -3.4 \\
\hline Leucine & 0.044 & 0.03 & -29.55 & 0.027 & -38.6 & 0.025 & -43.2 \\
\hline Lysine & 0.071 & 0.07 & -2.82 & 0.063 & -11.3 & 0.067 & -5.6 \\
\hline \multirow[t]{2}{*}{ Total } & 4.404 & 4.54 & 3.07 & 3.630 & -17.6 & 4.357 & -1.0 \\
\hline & $\mathrm{C}_{0}$ & $\mathrm{C}_{1}$ & Change, $\%^{a}$ & $\mathrm{C}_{2}$ & Change, \% & $\mathrm{C}_{3}$ & Change, \% \\
\hline Aspartic acid & 3.138 & 3.649 & 16.3 & 2.784 & -11.3 & 3.425 & 9.2 \\
\hline Glutamic acid & 0.357 & 0.438 & 22.7 & 0.300 & -16.0 & 0.390 & 9.2 \\
\hline Asparagine & 0.123 & 0.131 & 6.5 & 0.070 & -43.1 & 0.115 & -6.5 \\
\hline Serine & 0.198 & 0.204 & 3.0 & 0.182 & -8.1 & 0.264 & 33.3 \\
\hline Glutamine + histidine & 0.304 & 0.328 & 7.9 & 0.206 & -32.2 & 0.314 & 3.3 \\
\hline Glycine & 0.065 & 0.067 & 3.1 & 0.045 & -30.8 & 0.065 & 0.0 \\
\hline Threonine & 0.051 & 0.056 & 9.8 & 0.036 & -29.4 & 0.056 & 9.8 \\
\hline Alanine & 0.057 & 0.064 & 12.3 & 0.039 & -31.6 & 0.057 & 0.0 \\
\hline Arginine & 0.129 & 0.141 & 9.3 & 0.110 & -14.7 & 0.154 & 19.4 \\
\hline Tyrosine & 0.020 & 0.021 & 5.0 & 0.013 & -35.0 & 0.022 & 10.0 \\
\hline Methionine & 0.029 & 0.031 & 6.9 & 0.019 & -34.5 & 0.031 & 6.9 \\
\hline Phenylalanine & 0.081 & 0.076 & -6.2 & 0.043 & -46.9 & 0.069 & -14.8 \\
\hline Valine + tryptophan & 0.085 & 0.087 & 2.4 & 0.060 & -29.4 & 0.094 & 10.6 \\
\hline Isoleucine & 0.192 & 0.203 & 5.7 & 0.133 & -30.7 & 0.192 & 0.0 \\
\hline Leucine & 0.034 & 0.035 & 2.9 & 0.021 & -38.2 & 0.036 & 5.9 \\
\hline Lysine & 0.074 & 0.078 & 5.4 & 0.060 & -18.9 & 0.074 & 0.0 \\
\hline Total & 4.937 & 5.609 & 13.6 & 4.121 & -16.6 & 5.358 & 8.5 \\
\hline
\end{tabular}

${ }^{a}$ Change, $\%=100\left(A_{n} A_{o}\right) / A_{o}, 100\left(B_{n} B_{o}\right) / B_{o}$, and $100\left(C_{n} C_{o}\right) / C_{o}$ where $n=1,2$, and 3 .

${ }^{\mathrm{b}}$ Asparagine and serine were not identified in the $A$ samples. 
Table 5. Qualitative results of basic compounds identified in roasted burley tobaccos

\begin{tabular}{|c|c|c|}
\hline Compound & $\mathrm{RI}$ & $\begin{array}{l}\text { Rl' (Authentic } \\
\text { compound) }\end{array}$ \\
\hline Thiazole $^{\text {a }}$ & - & - \\
\hline Pyrrole $^{a}$ & - & - \\
\hline Pyridine ${ }^{a}$ & - & - \\
\hline Pyridine, 2-acetyl- & 1109 & 1108 \\
\hline Pyridine, 3-acetyl- & 1189 & 1183 \\
\hline Pyrazine, 2-methyl- & 940 & 943 \\
\hline Pyrazine, 2,3-dimethyl- & 996 & 996 \\
\hline Pyrazine, 2,5-dimethyl- & 987 & 986 \\
\hline Pyrazine, 2-ethyl-3-methyl- & 1080 & 1075 \\
\hline Pyrazine, trimethyl- & 1073 & 1072 \\
\hline Quinoline & 1318 & 1308 \\
\hline 2,3'-Bipyridine & 1646 & 1630 \\
\hline \multicolumn{2}{|l|}{ Compound } & $\begin{array}{c}\text { GC-MS } \\
\text { match qualities }\end{array}$ \\
\hline \multicolumn{2}{|l|}{ Aniline, 4-ethenyl- } & 72 \\
\hline & 91 \\
\hline \multicolumn{2}{|l|}{ sec-Butylamine } & 91 \\
\hline \multicolumn{2}{|c|}{ Cotinine } & 91 \\
\hline \multicolumn{2}{|c|}{ Imidazole, 4,5-dihydro-2-ethyl-4-methyl- } & 83 \\
\hline \multicolumn{2}{|c|}{ 2H-Indol-2-one, 1,3-dihydro-1,3,3-trimethyl- } & 76 \\
\hline \multicolumn{2}{|c|}{ Myosmine } & 94 \\
\hline \multicolumn{2}{|l|}{ Nicotyrine } & 94 \\
\hline \multicolumn{2}{|l|}{ Nornicotine } & 96 \\
\hline \multicolumn{2}{|l|}{ Nornicotine, $N$-formyl- } & 64 \\
\hline \multicolumn{2}{|c|}{ Oxazole, trimethyl- } & 76 \\
\hline \multicolumn{2}{|c|}{ Propionamide, $\mathrm{N}$-methyl-3-pyridinyl- } & 91 \\
\hline \multicolumn{2}{|c|}{ Pyrazine, 2-isopropyl-3,6-dimethyl- } & 58 \\
\hline \multicolumn{2}{|c|}{ Pyridine, 4-acetyl- } & 68 \\
\hline \multicolumn{2}{|l|}{ Pyridine, 4-benzyl- } & 76 \\
\hline \multicolumn{2}{|l|}{ Pyridine, 4-tert-butyl- } & 78 \\
\hline \multicolumn{2}{|l|}{ Pyridine, 3-(1-n-butyryl)- } & 87 \\
\hline \multicolumn{2}{|l|}{ Pyridine, 3-ethenyl- } & 87 \\
\hline \multicolumn{2}{|l|}{ Pyridine, 2-ethyl-6-methyl- } & 95 \\
\hline \multicolumn{2}{|l|}{ Pyridine, 3-formyl- } & 94 \\
\hline \multicolumn{2}{|l|}{ Pyridine, 3-phenyl- } & 94 \\
\hline \multicolumn{2}{|l|}{ Pyridine, 3-propionyl- } & 90 \\
\hline \multicolumn{2}{|l|}{ Pyridine, 2,3,5-trimethyl- } & 72 \\
\hline \multicolumn{2}{|c|}{ Pyrrole, 1-acetyl-2-pyridinyltetrahydro- } & 96 \\
\hline
\end{tabular}

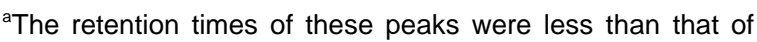
nonane, but they agreed with those of authentic thiazole, pyrrole, and pyridine.

\section{Comparison of free amino acids in control and roasted burley tobaccos}

The levels of 16 free amino acids were determined in the three roasted and control burley tobaccos. According to the data in Table 4, the following observations may be made:

1) Roasting with water: Among the three burley samples, the total amount of free amino acids increased (A: $10.33 \%$; B: $3.07 \%$; C: $13.61 \%$ ). The levels of seven amino acids increased in $\mathrm{A}$, the levels of 10 amino acids increased in $\mathrm{B}$, and the levels of 15 amino acids increased in $\mathrm{C}$.
2) Roasting with aqueous ammonia: The total amount of free amino acids in A and $\mathrm{C}$ increased (A: 10.33\%, C: $8.47 \%$ ), but that in B decreased by $1.02 \%$. The levels of 13 amino acid increased in $\mathrm{A}$, the levels of 8 amino acid increased in B, the levels of 14 amino acid increased in C.

3) Roasting with aqueous glucose: In the three burley samples, the total amount of free amino acids decreased (A: $20.73 \%$, B: $17.56 \%$, C: $16.53 \%$ ). Except for glycine and leucine, the levels of the other free amino acids decreased in A. Except for alanine, the levels of the other free amino acids decreased in B. The levels of all the amino acids decreased in $\mathrm{C}$. The levels of the following amino acids obviously decreased: Phenylalanine, asparagine, leucine, tyrosine, methionine, alanine, glycine.

The amino acids of burley tobacco leaves were involved in at least two competitive reactions during the roasting: a) Their generation by protein hydrolysis and b) their consumption in the Maillard reaction.

When the tobacco was roasted with water, the total amount of free amino acids increased, indicating the increase in amount due to protein hydrolysis was greater than the decrease due to the Maillard reaction. In contrast, when the tobacco was roasted with aqueous glucose, the amount of total free amino acids decreased, indicating that the added glucose consumed more amino acids.

\section{Changes in levels of basic compounds in burley tobaccos during roasting}

By comparing the retention index (RI) values or the standard mass spectral data [The Wiley/NIST Registry of Mass Spectral Data, 6th Edition (275,000 spectra of 226,000 compounds)], 36 basic compounds were qualitatively identified and their match qualities listed. No differences were observed in the number of basic compounds in burley tobacco during roasting. Table 5 summarizes the results.

Among the 36 basic compounds identified from the burley tobaccos were six pyrazines, 13 pyridines, and 17 other heterocyclic compounds. Figure 2 depicts the gas chromatograms.

An HP 5890 GC II equipped with a nitrogen-phosphorus detector, and an Ultra2 $(50 \mathrm{~m} \times 0.2 \mathrm{~mm}$ i.d. $\times 0.331 \mu \mathrm{m}$ film thickness) capillary column were used. After temperature programming from 70 to $270{ }^{\circ} \mathrm{C}$ at a rate of $2{ }^{\circ} \mathrm{C} / \mathrm{min}$, the temperature was maintained at $270{ }^{\circ} \mathrm{C}$ for $30 \mathrm{~min}$. The split ratio was 20:1. Injection port temperature was $260^{\circ} \mathrm{C}$; detector temperature was $270{ }^{\circ} \mathrm{C}$. Nitrogen was the carrier gas.

\section{Quantitative analysis of basic flavor components in burley tobacco during roasting}

Quantitatively, the levels of 19 basic compounds were determined. Table 6 summarizes the results. The total amount of basic components of burley tobacco decreased during roasting.

In this study, five pyrazines - 2,3-dimethyl- and 2,5dimethylpyrazine, 2-ethyl-3-methyl- and 2-ethyl-6-methylpyrazine, and trimethylpyrazine - known to be produced in the Maillard reaction (12) were identified. The total amount of pyrazines in burley tobacco increased during roasting. 

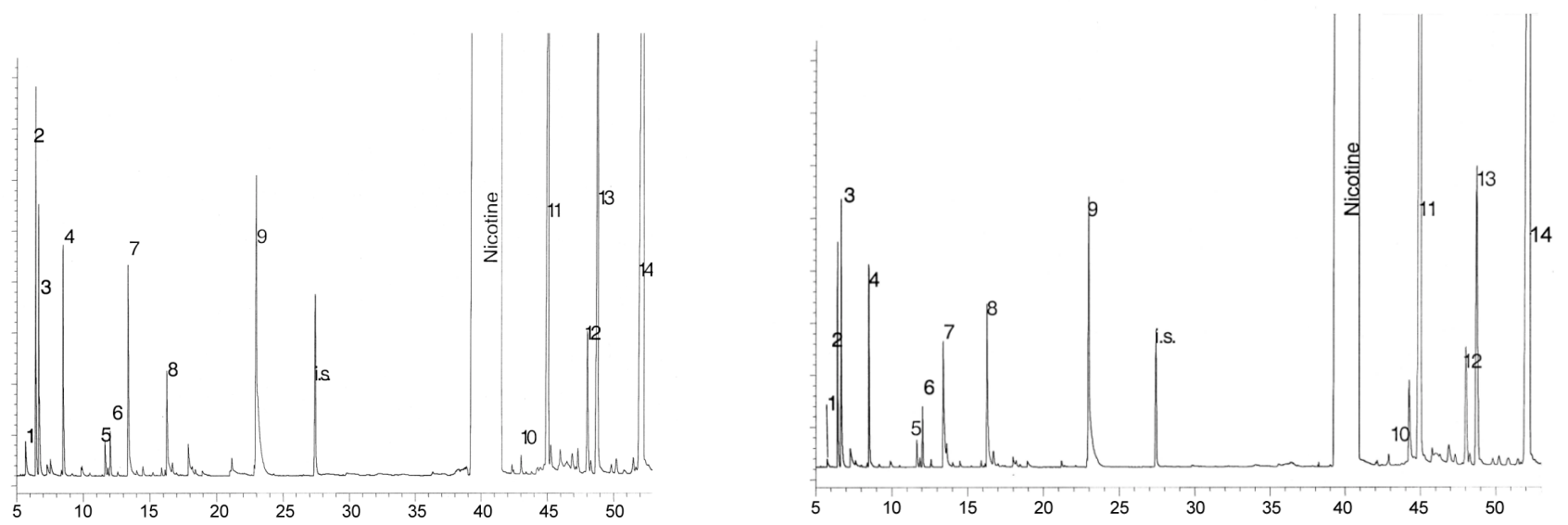

Figure 2. Gas chromatograms of the basic compounds in roasted burley tobacco: $1=$ thiazole; $2=$ pyrrole; $3=$ pyridine; 5 = 2-methylpyridine; 6 = 4,5-dihydro-2-ethyl-4-methylimidazole; $8=2,5$-dimethylpyrazine; $9=3$-acetylpyridine; $10=$ trimethyloxazole; 12 = 4-benzylpyridine; 13 = 2-tert-butylpyridine; 14 = 2,3'-bipyridine.

Table 6. Basic components in roasted burley tobacco: Quantitative data

\begin{tabular}{|c|c|c|c|c|c|c|c|c|c|c|c|c|}
\hline $\begin{array}{l}\text { Compound, } \\
\mu \mathrm{g} / \mathrm{g} \text { dried tobacco leaf }\end{array}$ & $\mathrm{A}_{0}$ & $A_{1}$ & $\mathrm{~A}_{2}$ & $\mathrm{~A}_{3}$ & $\mathrm{~B}_{0}$ & $\mathrm{~B}_{1}$ & $\mathrm{~B}_{2}$ & $\mathrm{~B}_{3}$ & $\mathrm{C}_{0}$ & $\mathrm{C}_{1}$ & $\mathrm{C}_{2}$ & $\mathrm{C}_{3}$ \\
\hline Pyrazine, 2,3-dimethyl- & 0.9 & 1.3 & 1.8 & 1.2 & 0.3 & 0.4 & 0.3 & 0.3 & 0.2 & 0.7 & 0.9 & 0.5 \\
\hline Pyrazine, 2,5-dimethyl- & 4.4 & 4.5 & 4.8 & 4.5 & 3.9 & 3.9 & 4.0 & 3.9 & 4.0 & 4.0 & 4.0 & 4.0 \\
\hline Pyrazine, 2-ethyl-3-methyl- & 12.9 & 13.4 & 13.6 & 13.0 & 5.0 & 5.8 & 6.0 & 7.0 & 6.4 & 7.6 & 6.5 & 6.7 \\
\hline Pyrazine, 2-ethyl-6-methyl- a & 0.7 & 0.8 & 0.8 & 0.7 & 0.5 & 0.6 & 0.5 & 0.5 & 0.6 & 0.7 & 0.6 & 0.7 \\
\hline Pyrazine, trimethyl- & 0.1 & 0.3 & 0.3 & 0.4 & 0.0 & 0.1 & 0.1 & 0.2 & 0.1 & 0.4 & 0.2 & 0.2 \\
\hline Total pyrazines & 19.0 & 20.3 & 21.3 & 19.8 & 9.7 & 10.8 & 10.9 & 11.9 & 11.3 & 13.4 & 12.2 & 12.1 \\
\hline Pyridine & 8.5 & 9.7 & 9.4 & 9.1 & 1.4 & 1.7 & 1.4 & 2.0 & 2.1 & 3.1 & 2.9 & 2.2 \\
\hline Pyridine, 2-acetyl- & 11.8 & 22.4 & 23.0 & 18.6 & 4.4 & 5.4 & 3.8 & 4.6 & 5.5 & 5.5 & 6.7 & 9.2 \\
\hline Pyridine, 3-acetyl- & 2.2 & 1.6 & 1.5 & 1.4 & 0.5 & 0.7 & 0.6 & 0.6 & 0.5 & 0.6 & 0.7 & 0.9 \\
\hline Pyridine, 4-acetyl- a & 0.3 & 0.5 & 0.2 & 0.6 & 2.9 & 3.1 & 1.1 & 3.3 & 0.4 & 0.6 & 0.2 & 0.6 \\
\hline Pyridine, 3-formyl- a & 0.6 & 0.7 & 1.1 & 0.7 & 0.2 & 0.2 & 0.1 & 0.2 & 0.3 & 0.8 & 0.4 & 0.3 \\
\hline Pyridine, 2-methyl- a & 0.2 & 0.3 & 0.2 & 0.2 & 0.1 & 0.1 & 0.1 & 0.1 & 0.1 & 0.2 & 0.5 & 0.1 \\
\hline Pyridine, 2,3,5-trimethyl- a & 1.2 & 1.9 & 2.2 & 1.8 & 0.1 & 0.2 & 0.3 & 0.2 & 0.2 & 0.8 & 0.6 & 0.7 \\
\hline Total pyridines & 24.8 & 37.1 & 37.6 & 32.4 & 9.6 & 11.4 & 7.4 & 11.0 & 9.1 & 11.6 & 12.0 & 14.0 \\
\hline Pyrrole & 9.0 & 13.5 & 14.1 & 12.6 & 4.0 & 5.0 & 3.0 & 4.0 & 6.1 & 9.5 & 7.8 & 6.5 \\
\hline Thiazole & 11.9 & 14.0 & 12.0 & 12.4 & 2.5 & 3.5 & 1.9 & 2.7 & 2.4 & 3.5 & 2.7 & 2.5 \\
\hline Oxazole, trimethyl- ${ }^{\text {a }}$ & 0.1 & 0.1 & 0.1 & 0.1 & - & 0.2 & 0.0 & 0.2 & 0.2 & 0.1 & 0.0 & 0.0 \\
\hline Quinoline $^{a}$ & 0.3 & 0.5 & 0.1 & 0.4 & 0.1 & 0.1 & 0.1 & 0.1 & 0.1 & 0.1 & 0.0 & 0.1 \\
\hline 2,3'-Bipyridine ${ }^{a}$ & 63.2 & 22.0 & 46.1 & 29.4 & 10.0 & 7.8 & 5.5 & 5.8 & 8.6 & 5.7 & 13.6 & 4.1 \\
\hline sec-Butylamine & 0.8 & 0.6 & 0.6 & 0.7 & 0.1 & 0.1 & 0.2 & 0.2 & 0.2 & 0.1 & 0.2 & 0.2 \\
\hline Aniline, $p$-ethenyl- & 40.3 & 36.4 & 40.6 & 34.2 & 2.9 & 2.0 & 0.9 & 1.9 & 5.3 & 4.8 & 5.2 & 3.6 \\
\hline Total bases & 224 & 192 & 234 & 187 & 47 & 47 & 34 & 44 & 60 & 79 & 73 & 60 \\
\hline Nicotine $^{a}$ & 9520 & 5620 & 8380 & 5530 & 3220 & 3100 & 2250 & 2375 & 8760 & 8265 & 4155 & 5435 \\
\hline
\end{tabular}

${ }^{a}$ The relative values were calculated as tributylamine equivalents; the others were derived from the regression equations.

The ranges of increase of trimethylpyrazine and 2,3dimethylpyrazine are most obvious. Dimethylpyrazine contributes popcorn flavor; trimethylpyrazine contributes roasting cocoa, peanut, and fried potato flavors. The increase in the amounts of these compounds plays an impor- tant role in the characteristic burley tobacco smoke flavor. As indicated in Table 6, seven pyridines were quantitated in this study. While their total amount increased during roasting, the amounts of pyridine, 2-acetylpyridine, 3formylpyridine, and 2,3,5-trimethylpyridine increased 
significantly. It has been reported that pyridine and 2,3,5trimethylpyridine have been applied in a tobacco flavor formulation to enhance the characteristic flavor of burley tobacco (13). Other investigators have suggested that several alkylated pyridines in tobacco smoke contribute to its undesirable taste and strength (14).

Pyrrole (produced in the Maillard reaction and the Strecker degradation) contributes a roasted bread flavor. Its amount increased during roasting.

Thiazole and several other heterocyclic nitrogen compounds were also identified. The levels of most of them increased during roasting.

The analytical results indicate that the total amount of amines in the burley tobaccos generally decreased during roasting, a decrease probably due to volatilization. The level of nicotine decreased in all three burley tobaccos roasted under different conditions.

\section{CONCLUSIONS}

High-temperature treatment of the burley tobacco is usually necessary in the manufacturing process involving a cigarette blend. Appropriate roasting conditions generate aroma and flavor compounds and remove amines, thereby making the smoke more acceptable, reducing irritation, modifying the tobacco $\mathrm{pH}$, and improving the quality of the burley tobacco. In this study, numerous analytical methods were used to determine the changes in the levels of burley tobacco components during roasting. The findings include:

1) The percentages of total nitrogen, total alkaloids, and total volatile amines in the tobacco decreased, thereby reducing the irritancy and unacceptable taste of the smoke. In addition, the tobacco $\mathrm{pH}$ decreased, a benefit to the organoleptic properties of the smoke.

2) Under the three different roasting conditions, the amounts of free amino acids and sugars changed rather significantly, demonstrating that the Maillard reaction occurred during roasting.

3) From the analytical results of the basic compound study, 36 were qualitatively identified in the burley tobacco. For the first time, 19 basic compounds were quantitatively determined before and after roasting and the results indicate that the amounts of heterocyclic compounds increased. Such compounds play an important role in the characteristic flavor of burley tobacco. In addition, the amounts of amines and alkaloids decreased which is an occurrence that improves the smoking quality of the burley tobacco.

\section{REFERENCES}

1. Long, R.C. and J.A. Weybrew: Major chemical changes during senescence and curing; Rec. Adv. Tob. Sci. 7 (1981) 40-74.
2. Burton, H.R., L.P. Bush, and J.L. Hamilton: Effect of curing on the chemical composition of burley tobacco; Rec. Adv. Tob. Sci. 9 (1983) 91-153.

3. Neurath, G., A. Krull, B. Pirmann, and K. Wandrey: Untersuchung der flüchtigen Basen des Tabaks. II [Examination of volatile bases in different types of tobacco II]; Beitr. Tabakforsch. 3 (1966) 571-576.

4. Roberts, D.L. and W.A. Rohde: Isolation and identification of flavor components of burley tobacco; Tob. Sci. 16 (1972) 107-112.

5. Demole, E. and D. Berthet: A chemical study of burley tobacco flavour (Nicotiana tabacum L.). I. Volatile to medium-volatile constituents; Helv. Chim. Acta. 6 (1972) 1866-1882.

6. Wang, P.S., H. Kato, and M. Fujimaki: Studies on flavor components of roasted burley; Agr. Biol. Chem. 32 (1968) 501-506.

7. Matsukura, M., K. Takahashi, M. Kawamoto, S. Ishiguro, and H. Matsushita: Recovery of roasted tobacco volatiles released from activated carbon by extraction and steam desorption methods; Agr. Biol. Chem. 9 (1984) 2245-2251.

8. Wu, M. and X.L. Wu: A study of burley material; Tob. Sci. Technol. 2 (1996) 9-11.

9. Du, J.S.: The effects of air temperature and humidity in the drying process on the smoking quality of toasted Burley tobacco; Proceedings, Paper presented at the occasion of the CORESTA Congress, Xi'an, China, 2001, p. 6.

10. Xiao, X.Z.: Tobacco chemistry; Agr. Sci. and Tech. Pub. Comp. of China, 1997, pp. 240-241.

11. Xie, F.W.: OPA ( $o$-phenyldialdehyde) auto-precolumn derivation reversed phase high performance liquid chromatography; 3rd National Member's Congress of China Tobacco Society, 1996, pp. 208-218.

12. Amrani-Hemaimi, M., C. Cerny, and L.B. Fay: Mechanisms of formation of alkylpyrazines in the Maillard reaction; J. Agr. Food Chem. 43 (1995) 2818-2822.

13. Jin, W.B. and Y.J. Zhang: Tobacco essence; Publishing Company of University of Science and Technology of China, 1996, p. 197.

14. Hoffmann, D. and E.L. Wynder: Smoke of cigarettes and little cigars: An analytical comparison; Science 178 (1972) 1197-1199.

Address for correspondence:

Li Peng

Zhengzhou Tobacco Research Institute of China National Tobacco Corp.,

No. 88 Erqi Road,

Zhengzhou, Henan, 450000,

P.R. China 